\title{
An ECM Analysis of Thai Tourism Demand in Malaysia
}

\author{
Fung-Thai Thien \\ Universiti Malaysia Sarawak \\ fungthai87@hotmail.com \\ Chin-Hong Puah \\ Universiti Malaysia Sarawak \\ chpuah@feb.unimas.my \\ MKH Hassan \\ Universiti Malaysia Sarawak \\ hmkhisyam@feb.unimas.my \\ M Affendy Arip \\ Universiti Malaysia Sarawak \\ amaffendy@feb.unimas.my
}

\section{Doi:10.5901/mjss.2015.v6n3p162}

\section{Abstract}

Tourism industry is one of the important service industries that play a crucial role in the development of Malaysian economy. Thailand has been ranked among the top five tourist generating countries for Malaysia since the last decade. This paper intends to determine factors affecting Thai tourism demand in Malaysia from the macroeconomic perspective by utilizing quarterly data from 2000Q1 to 2013Q4. The Thai tourism demand model is estimated using the error-correction model and a battery of diagnostic tests were carried out to ensure the robustness of the model. The empirical results indicate that there is a long-run equilibrium relationship between Thai tourism demand and the specified explanatory variables, which are Thai real income, real travel cost and exchange rate. Specifically, higher Thai real income will reduce Thai tourist to Malaysia, while higher real travel cost and stronger currency attract more Thai visitor to Malaysia. As a conclusion, this paper has achieved its aim to determine the factors affecting Thai tourism demand in Malaysia.

Keywords: Tourism demand, error-correction model, macroeconomic

\section{Introduction}

Malaysian government has given attention to its tourism industry following the poor performances of Malaysia's primary commodities and manufacturing industry, which were resulted by the oil price drop and economic recession in the mid1980s. The Ministry of Culture, Arts and Tourism was established by Malaysian government in 1987, and was upgraded to Ministry of Tourism in 2004.

In order to promote Malaysia to tourists around the globe, a series of promotion campaign was implemented since 1990s. The famous Visit Malaysia Year programme was carried out in 1990, 1994, 2000 and 2007. At the same time, Malaysia also organizes annual events such as the World Amateur Inter-team Golf Championship, the Rainforest World Music Festival and the Borneo International Jazz Festival, which attract mass arrival of international tourist.

According to World Travel and Tourism Council (WTTC) (2014), Malaysia's tourism industry contributed 16.1 percent (RM 158.2 billion) to its GDP in 2013. WTTC (2014) forecasted this contribution to increase further to 16.4 percent of GDP (RM 168.9 billion) in 2014. Furthermore, Malaysian tourism industry contributed 14.1 percent (1.86 million jobs) of total employment in 2013 and is projected to contribute to 14.5 percent (1.95 million jobs) of total employment in 2014.

In addition, the role of tourism industry is highlighted in the Economic Transformation Programme (ETP), which is introduced to lead Malaysian economy towards achieving the status of high income nation by 2020. A successful ETP will 
divert Malaysia into service-based economy in which service sector will contribute to 65 percent of GDP. Under ETP, 12 National Key Economic Areas (NKEAs) are identified as the key engines of growth and tourism industry is included in the list.

Malaysia has a strong position for its tourism industry as it was ranked in top 10 for both the most visited country and tourist arrival in the world, as well as ranked in top 15 in terms of global receipts (PEMANDU, 2010). Therefore, it is important to study the factors affecting tourism demand in Malaysia as this particular industry will play an important role in the future development of Malaysian economy.

Thailand was ranked second in tourist generating countries for Malaysia from 2000 until 2006. Nevertheless, Thailand's ranking has dropped to be the fifth tourist generating country for Malaysia starting from 2012. Despite this, the average annual growth for Thai visitor arriving into Malaysia is 2.43 percent for the period 2000 to 2013. Table 1 shows the number of Thai tourist arrival into Malaysia, their market share and annual growth from 2000 to 2013.

Table 1: Thai Market Analysis in Malaysia's Tourism Industry

\begin{tabular}{cccc}
\hline Year & Tourist Arrival (Person) & Market Share (Percentage) & Annual Growth (Percentage) \\
\hline 2000 & 940,215 & 9.2 & 88.6 \\
2001 & $1,018,797$ & 8.0 & 8.4 \\
2002 & $1,166,937$ & 8.8 & 14.5 \\
2003 & $1,152,296$ & 10.9 & -1.3 \\
2004 & $1,518,452$ & 9.7 & 31.8 \\
2005 & $1,900,839$ & 11.6 & 25.2 \\
2006 & $1,891,921$ & 10.8 & -0.5 \\
2007 & $1,625,698$ & 7.8 & -14.1 \\
2008 & $1,493,789$ & 6.8 & -8.1 \\
2009 & $1,449,262$ & 6.1 & -3.0 \\
2010 & $1,458,678$ & 5.9 & 0.6 \\
2011 & $1,442,048$ & 5.8 & -1.1 \\
2012 & $1,263,024$ & 5.0 & -12.4 \\
2013 & $1,156,452$ & 4.5 & -8.4 \\
\hline
\end{tabular}

Source: Tourism Malaysia (2014).

As depicted in Table 1, Thai tourist arrival has shown an upward trend from 2000 to 2005, with the highest tourist arrival in 2005 (accounted for 11.6 percent of total tourist arrival in Malaysia). However, since 2006, Thai tourist arrival has shown a downward trend until 2013 with the highest negative annual growth of 14.1 percent in 2007. The decreasing Thai tourist arrival in recent years has raised the needs to study the factors affecting Thai tourist arrival into Malaysia. The main objective of this paper is to empirically examine the Thai tourism demand in Malaysia from a macroeconomic perspective.

\section{Literature Review}

In the study of tourism demand, tourist arrival has been utilized by a number of studies such as Dritsakis (2004), GarinMunoz and Montero-Martin (2007), Ouerfelli (2008), Habibi et al. (2009), Kusni et al. (2013) and Kadir et al. (2013) to represent tourism demand. In Dritsakis's (2004) study, the author found that the real income of origin country is significant and elastic for both German and UK tourists visiting Greece.

Other researchers such as Ouerfelli (2008), Botti et al. (2007) and Brida et al. (2008) also obtained results supporting elastic coefficient for income in the cases of France, Mexico and Tunisia, respectively. The elastic income coefficient indicates that tourism is a luxury good given that demand increases more than proportionate to a change in income.

On the other hand, Garin-Munoz (2006) pointed out that transportation cost or travel cost is also an important explanatory variable to be included in tourism demand study. This variable measures the travel expenditure of tourist to travel from their origin country to the tourism destination and this expenditure makes up a considerable part of total expenditure of their trip. Dritsakis (2004) and Nelson et al. (2011) are among the researchers who have included travel cost in examining tourism demand. Both authors utilized the airfare to measure the travel cost in their study.

Nevertheless, Mohd Salleh et al. (2007) revealed that difficulty exists in determining the exact flight that tourist bought and hence the amount of airfare paid. As such, Mohd Salleh et al. (2007) suggested to proxy travel cost using 
crude oil price. This proxy is also used in number of studies such as Garin-Munoz and Montero-Martin (2007), GarinMunoz (2006), Mohd Salleh et al. (2008) and Habibi and Abdul Rahim (2009).

In addition, exchange rate is evidenced to be a significant variable to explain tourism demand as revealed in the studies by Dritsakis (2004), Ouerfelli (2008), Mohd Salleh et al. (2007) and Mohd Salleh et al. (2008), to name a few. The appreciation of origin country's currency against the destination's currency will encourage tourists to travel as their spending power has increased and they are able to purchase more goods and services in tourist destination.

According to Purchasing Power Parity, the depreciation or appreciation of the exchange rate also reflects the difference in the rate of prices (or the difference in inflation rates) in origin country and destination country. Thus, exchange rate variable carries the information of both price levels in tourist origin country and tourism destination. The price levels carry information of cost of living in the destination as compared to the country of origin.

\section{Model, Data and Methodology}

The following function is used in examining Thai demand for tourism in Malaysia:

$$
T A=F(Y, T C, E X)
$$

where TA represents Thai tourist arrival to Malaysia, $Y$ proxies the real income of Thai, TC is the real travel cost and $E X$ is the exchange rate between Thailand and Malaysia.

A positive relationship is expected to exist between Thai real income and tourism demand in Malaysia. This indicates that an increase in Thai real income will encourage more Thai tourist to visit Malaysia and vice versa, a decline in Thai real income subsequently will reduce the Thai tourist visiting Malaysia. Thai real income is computed by deflating Thai GDP with its consumer price index (CPI).

Meanwhile, real travel cost is expected to have a negative relationship with Thai tourist inflow to Malaysia. Higher real travel cost would increase the total cost of the trip and reduce the visiting Thai tourist to Malaysia. The real travel cost proxy used in this study is real crude oil price. Real crude oil price is calculated by deflating crude oil price with the CPI of the US.

The existence of a positive relationship between exchange rate and tourism demand is expected, which in particular, the appreciation of Thai Baht will encourage more Thai visitors travelling to Malaysia and vice versa, Thai Baht depreciation will decrease the number of Thai tourists visiting Malaysia. The exchange rate variable used in this study is the ratio of currency between Malaysia and Thailand.

The tourism demand model to be examined in this study is expressed as follow:

$$
L T A=\beta_{0}+\beta_{1} L Y_{t}+\beta_{2} L T C_{t}+\beta_{3} L E X_{t}+\varepsilon_{t}
$$

The data for Thai tourist arrival were collected from Tourism Malaysia ${ }^{1}$, while the data used to compute Thai real income and exchange rate were collected from International Financial Statistics (IFS) published under International Monetary Fund (IMF) and for travel cost, crude oil price data were obtained from Global Economic Monitor published by World Bank. All variables were transformed into natural logarithm form before conducting any estimation. The period covered in this study is from 2000Q1 to 2013Q4, utilizing quarterly observation.

The empirical testing procedures started off by examining the time series properties of the variables utilizing the Augmented Dickey-Fuller test (ADF) unit root test (Dickey and Fuller, 1979; 1981). The next step after identifying the time series properties of the variables was to test for long-run relationship among the variables by implementing the Johansen and Juselius multivariate cointegration test (Johansen and Juselius, 1990).

Once the long-run cointegration relationship was established, Error-Correction Model (ECM) was carried out to determine the interaction among the variables. ECM is also able to investigate the speed of adjustment of the dependant variable back to equilibrium when there are changes in explanatory variables. Short-run Granger causality test result was obtained from ECM before running a series of diagnostic tests to ensure that the model is robust.

\section{Empirical Results}

\subsection{Unit root test results}

This study utilized ADF unit root test to determine the time series properties of variables. Table 2 shows the results of ADF unit root test. The null hypothesis of unit root is not rejected at the level, but it is rejected after first differencing.

${ }_{1}^{1}$ Data of tourist arrival from Thailand is downloaded and compiled from http://corporate.tourism.gov.my/research.asp?page=facts_figures. 
Hence, all variables were integrated of order one or I(1) as illustrated in Table 2.

Table 2: ADF Unit Root Test Results

\begin{tabular}{ccc}
\hline Variable & Level & First Difference \\
\hline LTA & $-1.137(3)$ & $-5.096(3)^{\star \star \star}$ \\
LY & $-1.218(3)$ & $-4.376(3)^{\star \star \star}$ \\
LTC & $-2.471(3)$ & $-4.388(3)^{\star \star \star}$ \\
LEX & $-2.706(3)$ & $-5.482(3)^{\star \star \star}$ \\
\hline
\end{tabular}

Notes: LTA = natural log of tourist arrival, LY = natural log of real income, LTC = natural log of real travel cost, and LEX $=$ natural log of exchange rate. Asterisk $\left.{ }^{(* *}\right)$ indicates significant at 1 percent level. The lag selection criteria is based on Schwert (1987) criteria.

\subsection{Multivariate cointegration test results}

Once the variables were identified to be integrated of order one, Johansen and Juselius multivariate cointegration test was implemented to determine the number of cointegrating vector(s) in the model. The null hypothesis of zero cointegration $(r=0)$ is rejected by both maximum eigenvalue and trace statistics at 5 percent level of significance as shown in Table 3. However, we are not able to reject the null hypothesis of at most one cointegrating vector. Thus, the existence of a single cointegrating vector in the model lead us to presume that there is a long-run relationship among the variables in the model.

Table 3: Johansen and Juselius Cointegration Test Results

\begin{tabular}{llll}
\hline $\mathrm{H}_{0}$ & $\mathrm{H}_{1}$ & $\lambda_{\max }$ & $\lambda_{\text {trace }}$ \\
\hline \multicolumn{2}{l}{ Variable: LTA, LY, } & LTC, LEX & \\
$r=0$ & $r=1$ & $35.510^{\star \star}$ & $57.165^{\star \star}$ \\
$r \leq 1$ & $r=2$ & 15.057 & 21.654 \\
$r \leq 2$ & $r=3$ & 4.354 & 6.597 \\
$r \leq 3$ & $r=4$ & 2.242 & 2.242 \\
\hline
\end{tabular}

Notes: $r$ is the number of cointegrating vectors. Asterisk (**) indicates significant at 5 percent level. The optimal lag lengeth for VAR model is three, which is selected based on Schwert (1987) criteria.

\subsection{Normalized cointegrating vector estimates}

The evidence of long-run equilibrium relationship found in the cointegration test allows us to normalize the obtained cointegrating vector with respect to the dependant variable (LTA) in order to obtain the long-run estimates of the independent variables. The following equation shows the estimated results acquired from vector error correction estimates:

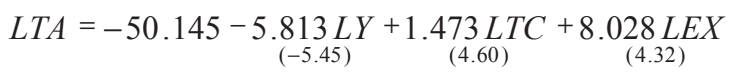

The $t$-statistic is reported in the parentheses and indicates that all the estimated coefficients are statistically significant at 1 percent level. The estimated sign of real income is negative, which contradicts the theory. Higher Thai real income in this case will lead to the decrease in Thai tourist arrival to Malaysia. The possible explanation behind this phenomenon is that Thai tourist with higher income seek for alternate tourism destinations in other countries rather than their neighbouring countries. The increase in income will encourage Thai tourist to travel to other tourism destinations which previously may be perceived as expensive and unaffordable for them.

Real travel cost is identified to have a positive relationship with Thai tourist arrival into Malaysia. In other words, increase in real travel cost will increase visiting Thai tourist to Malaysia. This positive relationship can be explained by considering the possibility that higher real travel cost will subsequently increases airfare, which discourages Thai visitors to travel via airline services. Therefore, as an alternative, they tend to use their own transportations to travel to Malaysia, their neighbouring country.

In relation to that, Thai visitors are also more probable to travel to Malaysia using their own transport as they can 
take the advantage to buy petrol in Malaysia, which is cheaper due to the subsidies provided by Malaysian government. A trip to Malaysia using their own transportation would be pleasant for Thai tourists as they can enjoy their travelling trip in Malaysia and return home purchasing cheaper petrol at the same time.

Finally, exchange rate has a plausible sign and in line with past literature. The positive relationship between exchange rate and tourism demand implies that appreciation of Thai Baht will increase Thai tourist travelling to Malaysia. Thai visitor will perceive that they are wealthier when their currency appreciates as more unit of Malaysian Ringgit can be exchange by a unit of Thai Baht. This situation will lead Thai to perceive that travelling and spending in Malaysia is cheaper than before.

\subsection{Estimation of error-correction model}

In Table 4, the summarized estimation of ECM for Thai tourism demand in Malaysia is presented. The model passes all the diagnostic tests. The estimated residuals are normally distributed with constant variances, free from serial correlation and misspecification. In addition, the CUSUM and CUSUM of squares stability tests indicate that the model is stable within the period of study.

Table 4: Estimation of Error-Correction Model

\begin{tabular}{cccc}
\hline Variable & Coefficient & $t$-statistic & $p$-value \\
\hline Constant & 0.006 & 0.216 & 0.829 \\
$\Delta \mathrm{LY}_{\mathrm{t}-1}$ & 1.812 & 2.575 & 0.013 \\
$\Delta \mathrm{LTC} \mathrm{t}_{\mathrm{t}-2}$ & -0.275 & -1.772 & 0.082 \\
Dum2001Q4 & -0.630 & -3.181 & 0.002 \\
$\mathrm{ECT}(-1)$ & -0.246 & -3.157 & 0.002 \\
\hline$R^{2}$ & Diagnostic Tests: & \\
$\bar{R}^{2}$ & 0.341 & ARCH[1] & $1.068[0.306]$ \\
$\mathrm{JB}$ & 0.286 & $\mathrm{RESET}$ & $0.189[0.665]$ \\
$\mathrm{AR}[2]$ & $3.297[0.192]$ & CUSUM & Stable \\
\hline
\end{tabular}

Notes: JB is the Jarque-Bera statistic for testing normality, AR[2] and ARCH[1] are the Langrange Multiplier tests for 2nd order serial correlation and ARCH effects, respectively. RESET refers to the Ramsey RESET specification test while CUSUM and CUSUM2 refer to CUSUM and CUSUM of squares stability tests.

The estimated error-correction term (ECT) is statistically significant and has the correct negative sign for its coefficient, which implies that the variables in the system are cointegrated in long-run (Kueh et al, 2009). As suggested by the ECT value, approximately 24.6 percent of short-run deviations of tourism demand will be adjusted in quarterly basis towards the long-run equilibrium state 2 .

Table 5 demonstrates the short-run causality test results obtained from the ECM. The null hypothesis of no causal relationship is rejected for real income and real travel cost at 5 and 10 percent significant levels, respectively. This implies that tourism demand is influenced by both variables in the short-run. This also suggests that Thai visitors are influenced by the wealth effect, where they perceive they are wealthier when their real income increases and travel more often to Malaysia in the short-run. Moreover, Thai travellers are also responsive to the changes in travel costs, where they have the alternative to travel to Malaysia using their own transports when travel cost increases in the short-run.

Table 5: Short-run Granger Causality Test Results

\begin{tabular}{lcc}
\hline $\mathrm{H}_{0}$ & $p$-value & Causal Inference \\
\hline LY does not Granger cause LTA & 0.013 & Reject $\mathrm{H}_{0}$ \\
LTC does not Granger cause LTA & 0.082 & Reject $\mathrm{H}_{0}$ \\
\hline
\end{tabular}

${ }^{2}$ A dummy variable (Dum2001Q4) is included in the ECM to capture the impact of terrorist attack in September 2001. 


\section{Summary and Conclusion}

This study examines the factors affecting Thai tourist arrival into Malaysia from the macroeconomic point of view. The independent variables utilized in this study are real income, real travel cost and exchange rate. First of all, time series properties of the variables were identified to be I(1) by the ADF unit root test. Next, Johansen and Juselius multivariate cointegration test confirmed the existence of long-run equilibrium relationship among the variables under study.

The normalized equation shows that two of the variables have reversal sign and one with plausible sign. The reversal sign of real income is possible considering Thai visitor may travel to other countries in the long-run when their real income increases. They feel that they afford to travel to other countries rather than only their neighbouring country.

On the other hand, the positive sign of real travel cost is viewed with the possibility that an increase in real crude oil price (proxy for real travel cost) will increase airfare and subsequently, Thai visitors may choose to travel to Malaysia using their own transportation. Another probable explanation is the airfares travelling to Malaysia are relatively cheaper as compared with airfares to other countries, although both airfares may have increased.

Exchange rate is the only variable with plausible sign in line with past literature. In the long-run, appreciation of Thai Baht will increase Thai tourist to Malaysia as one unit of Thai Baht can be exchanged for more units of Malaysian Ringgit. In other words, goods and services in Malaysia are relatively cheaper and this will attract more Thai tourists into Malaysia.

ECM was performed to determine the interaction between the variables of study. Results obtained from the ECM once again confirmed the existence of long-run equilibrium relationship among the variables in the model. Short-run deviations will be adjusted back towards the long-run equilibrium. In addition, Granger causality test was carried out and the results indicated that real income and real travel cost could be used to predict the future movement of Thai tourist.

Policy implications that can be suggested in this study are to improve the attractions of Malaysia's tourism, and to increase the promotion of Malaysia's tourism in Thailand. In the long run, less Thai tourists will travel to Malaysia because as their real income increases, they start to travel to other countries. Therefore, tourism authorities in Malaysia should increase the attractiveness of their tourism destinations to ensure that Thai visitors revisit Malaysia because of these attractions. These attractions may exist in the form of uniqueness of its cultures, products and the environment in the destinations.

Also, Thai visitors who are satisfied of their trip to Malaysia or, are attracted by the uniqueness of Malaysia's tourism will share their experiences with their friends and families. Therefore, increasing promotion of Malaysia's tourism is parallel with the spread of information about Malaysia's tourism to attract potential Thai visitors. The spread of information together with the timely promotion of Malaysia's tourism is able to grasp Thai tourists as such pertinent information will ease the concern regarding safety of the destination.

Additionally, by knowing that Thai tourists are likely to travel to Malaysia when the travel cost increases, Malaysia should prepare to welcome Thai tourists when an increase in the real crude oil price (the proxy for real travel cost) is observed. Once again, a timely promotion campaigns in Thailand during the period of increasing travel cost is expected to attract more Thai tourist arrival.

In short, tourism sector in Malaysia plays an important role in developing its economy, not only in the past but in the future as well. Since WTTC has pointed out that tourism industry has a wider impact on an economy via its direct and also indirect or induced contributions, it is essential to study the factors affecting tourist arrival to Malaysia. This study focused on determining the factors affecting tourist arrival to Malaysia for the case of Thailand, which ranked fifth in the tourist generating countries for Malaysia. With the knowledge of factors affecting tourist arrival to Malaysia, Malaysia tourism authorities can design appropriate policies to attract more international visitors.

\section{Acknowledgement}

The authors acknowledge the financial support of Universiti Malaysia Sarawak via Dana Principal Investigator: 03(DPI03)/793/2011(03).

\section{References}

Botti, L., Peypoch, N., Randriamboarison, R. \& Solonandrasana, B. (2007). An Econometric Model of Tourism Demand in France. Tourismos: An International Multidisciplinary Journal of Tourism, 2(1), 115-126.

Brida, J. G., Risso, W. A. \& Carrera, E. (2008). A Long-run Equilibrium Demand Function: Tourism in Mexico. Tourismos: An International Multidisciplinary Journal of Tourism, 3(1), 66-82. 
Dickey, D. A. \& Fuller, W. A. (1979). Distribution for the Estimators for Autoregressive Time Series with Unit Root. Journal of American Statistical Association, 74, 427-431.

Dickey, D. A. \& Fuller, W. A. (1981). Likelihood Ratio Statistics for Autoregressive Time Series with a Unit Root. Econometrica, 49, 10571072.

Dritsakis, N. (2004). Cointegration Analysis of German and British Tourism Demand for Greece. Tourism Management, 25(1), $111-119$.

Garin-Munoz, T. (2006). Inbound International Tourism to Canary Islands: A Dynamic Panel Data Model. Tourism Management, 27(2), 281-291.

Garin-Munoz, T. \& Montero-Martin, L. F. (2007). Tourism in the Balearic Islands: A Dynamic Model for International Demand Using Panel Data. Tourism Management, 28(5), 1224-1235.

Habibi, F. \& Abdul Rahim, K. (2009). A Bound Test Approach to Cointegration of Tourism Demand. American Journal of Applied Sciences, 6(11), 1924-1931.

Habibi, F., Abdul Rahim, K., Ramachandran, S. \& Chin, L. (2009). Dynamic Model for International Tourism Demand for Malaysia: Panel Data Evidence. International Research Journal of Finance and Economics, 33, 207-217.

IMF. International Financial Statistics, various issues, IMF, Washington D.C.

Johansen, S. \& Juselius, K. (1990). Maximum Likelihood Estimated and Inference on Cointegration with Application to the Demand for Money. Oxford Bulletin of Economics and Statistics, 52, 169-210.

Kadir, N., Nayan, S. \& Abdullah, M. S. (2013). A Panel Data Analysis of International Tourist Arrivals from ASEAN Countries to Malaysia. Procedia Economics and Finance, 7, 80-85.

Kueh, J. S. H., Puah, C. H. \& Abu Mansor, S. (2009). Empirical Analysis on Emerging Issues of Malaysia Outward FDI from Macroeconomic Perspective. International Review of Business Research Papers, 5(1), 124-134.

Kusni, A., Kadir, N. \& Nayan, S. (2013). International Tourism Demand in Malaysia by Tourists from OECD Countries: A Panel Data Econometric Analysis. Procedia Economics and Finance, 7, 28-34.

Mohd Salleh, N. H., Othman, R. \& Ramachandran, S. (2007). Malaysia's Tourism Demand from Selected Countries: The ARDL Approach to Cointegration. International Journal of Economics and Management, 1(3), 345-363.

Mohd. Salleh, N. H., Law, S. H., Ramachandran, S., Shuib, A. \& Mohd. Noor, Z. (2008). Asian Tourism Demand for Malaysia: A Bound Test Approach. Contemporary Management Research, 4(4), 351-368.

Nelson, L. A., Dickey, D. A. \& Smith, J. M. (2011). Estimating Time Series and Cross Section Tourism Demand Models: Mainland United States to Hawaii Data. Tourism Management, 32(1), 28-38.

Ouerfelli, C. (2008) Co-integration Analysis of Quarterly European Tourism Demand in Tunisia. Tourism Management, 29(1), $127-137$.

PEMANDU. (2010). Economic Transformation Programme: A Roadmap for Malaysia, PEMANDU.

Schwert, G. W. (1987). Effects of Model Specification Tests for Unit Root in Macroeconomic Data. Journal of Monetary Economics, 20, 73-103.

Tourism Malaysia. (2014). Facts and Figures. [Online] Available: http://corporate.tourism.gov.my/research.asp?page=facts_figures (January 30, 2015)

World Bank. (2014). Global Economic Monitor. [Online] Available: http://data.worldbank.org/data-catalog/global-economic-monitor (January 30, 2015)

WTTC (2014) Travel and Tourism Economic Impact 2014: Malaysia, WTTC, London. 